DOI: 10.14807/ijmp.v10i4.1001

\title{
EFFECT OF LOGISTICAL CONTROL IN CUSTOMER SATISFACTION IN A COMPANY IN THE PACKING SECTOR
}

\author{
Alcir das Neves Gomes \\ Instituto Federal de Educação, Ciência e tecnologia de São \\ Paulo, Campus Suzano; FATEC Zona Sul, Brazil \\ E-mail: alcir.gomes@ifsp.edu.br \\ Everton Santana Figueiredo \\ Instituto Federal de São Paulo, Campus- Suzano, Brazil \\ E-mail: everton_figueiredo@hotmail.com
}

Submission: 01/31/2019 Accept: 02/10/2019

\section{ABSTRACT}

logistics has become a strategic activity along the time not only a mere operational task in corporations, for that reason having a suitable management for logistics processes bring benefits all over the companies and impacts customer satisfaction. This paper was developed based on a case study performed in a packaging company located in the east area of the city of São Paulo, it was conducted in the period from April to September of 2017. An evaluation of logistical processes was performed based on nonparticipative observations and posteriorly with participative observations, with the diagnosis of main problems corrective actions were implemented as well as processes control. A training program was done to prepare the workers to accomplish with the new procedures, that made possible to stablish a comparison between past results and the ones achieved with new procedures and controls. It was also proposed and utilized the Net Promoter Score - NPS method to evaluate customer satisfaction that allowed to observe the results evolution achieved with the new procedures implemented.

Keywords: logistics processes control; customer satisfaction; Net Promoter Score - NPS 
DOI: 10.14807/ijmp.v10i4.1001

\section{INTRODUCTION}

Brazilian Market faces the financial sustainability challenge, due to the economic crises that reached the country in 2014, causing a long recession in the years of 2015 and 2016, with an average decline of $3.75 \%$ on GNP (PAULA; PIRES, 2017). According to Fatas and Summers (2016) studies, deep recessions increase costs and have effects on potential GNP and depressing economic growth.

Consequently, the revenues become highly compromised with arrears, turn debtors more vulnerable to shocks that can reduce cash generation, consequently reducing their capacity to honor their debts (PAULA; PIRES, 2017). Naturally, companies are doing what is possible, to reduce costs to improve profits and be more competitive. Competitiveness is a constant issue to companies, so it is necessary to innovate, and produce are solutions to business survival in such scenario (LANDIM et al., 2016).

In modern Society packaging has an important role to measure economic activity in industrialized countries, its consumption by the populations is one of the parameters to verify economic activity level as well as country development (LANDIM et al., 2016). According to Brazilian Cellulose and Paper Association (BRACELPAs, 2016), Brazil is worldwide noteworthy by producing and supplying relevant volume of paper and packaging materials.

Analyzing the packaging market Evolution, it is observed that Brazil became the world's 9th largest paper producer o with 10,260 metric tons as informed by Pulp and Paper Industry Intelligence (RISI, 2010), it represents $R \$ 42.8$ billion, around $1.10 \%$ of the Gross National Product (GNP). In 2013 according to the analysis of Brazilian Packaging Association (ABRE) on the first trimester of that year there was a reduction of $1.02 \%$ comparing to the GNP of 2012 and $11.82 \%$ comparing to 2010 GNP. The fluctuation between packaging production and participation on the GNP from 2010 to 2017 can be observed on the table 1 .

In 2016 a research from Brazilian Institute of Economy (IBRE) and Fundação Getulio Vargas (FGV) to ABRE, have indicates that the packaging sector achieved a production growth, achieving $R \$ 68$ billion, equivalent to $1.03 \%$ of Brazilian's GNP, comparing to 2013 it represents a $6.2 \%$ increase. In 2017 the same institutes produced 
a new research which demonstrates production value of $R \$ 71.5$ billion, a growth of $5.1 \%$, but a small decrease to $1.02 \%$ of the GNP (ABRE, 2017)

\begin{tabular}{|c|c|c|}
\hline Year & Gross Packaging Production ( $\mathrm{R} \$$ billions) & \%GNP* \\
\hline 2010 & 42.8 & 1.10 \\
\hline 2011 & 45.0 & 1.03 \\
\hline 2012 & 47.2 & 0.98 \\
\hline 2013 & 51.5 & 0.97 \\
\hline 2014 & 57.7 & 1.00 \\
\hline 2015 & 59.0 & 1.01 \\
\hline $2016^{\star *}$ & 68.0 & 1.03 \\
\hline $2017^{* *}$ & 71.5 & 1.02 \\
\hline
\end{tabular}

From total packaging production, plastics represent $38.85 \%$, followed by cellulosic packaging $34.09 \%$ (corrugated paperboard $17.36 \%$, cardboard $11.57 \%$ and paper $5.16 \%$ ), metallic packaging $18.15 \%$, glass $4.44 \%$ and wood $1.95 \%$ (ABRE, 2017).

Due to the access to information and the relevance it was chosen the cellulosic sector to perform de research. A case study was conducted in a packaging company located at east zone of São Paulo City, there was a data collection from April to September 2017. The research problem came up from the need to understand what is the impact of logistics services on customer satisfaction? The general objective of this paper is to measure the impact of logistics process control, transport operations and distribution on the company's customer satisfaction. The specific objectives are to check if there are logistics control system in the company, evaluate the financial impact of logistics activities and propose corrective measures to the logistics problems found during the research.

\section{LITERATURE REVIEW}

Corporations need to be profitable, to achieve this goal it is fundamental to obtain revenues and control costs, to have a health and sustainable business. As mentioned by Casagranda, Sauer and Pereira (2016), the main factors that interfere to consider a company as sustainable are resources utilized and organizational ethics. To Evangelista (2010), sustainability can be a competitive advantage that can increase profits. 
Corporations search for various strategies to identify the best mean to guarantee customer satisfaction, meanwhile they need to keep control of costs and results, aiming to maximize revenues and profits. Management process is crucial to achieve results, generally organizations have a departmental view, creating delays and compromising global performance. One of the great difficulties is to change cultural view from departmental to process based management (SOUZA; ZWICKER, 2003).

Hardly ever departments will disappear due to the process view, it would have a decrease, decentralization, responsibility change, without department extinction. Corporation would tend to be centralized in processes achieving higher maturity, allowing the existence of both functional and processes views (FONSECA, 2015).

Logistical process is a significant process for companies. The Association Française des Logisticiens d'Enterprises (L'ASLOG, 2010), defines logistics as series of activities that aims to deliver at a minimum cost, a quantity of product on place and time that exists the need.

Logistics mission is to put on the right goods or services in the correct place and time, with desirable conditions, providing the best contribution to the company (BALLOU, 2001). Logistics covers all the activities of moving warehousing to assist the flow of goods and information to provide the adequate service level at a reasonable cost. Logistics involves not only product delivery to customers, but inventories and production control, starting even before manufacturing or dispatch of goods to clients. (BALLOU, 2006).

Currently corporations are giving great emphasis to the Supply Chain Management (SCM), controlling the whole process from inbound of supplies to the delivery to customers, some authors define SCM as an extension of integrated logistics (CHRISTOPHER, 1997). Logistics management first concerned with optimization of internal processes, the concept of SCM considers that internal integration is not enough.

In fact, it is necessary to expand logistical integration beyond the company boundaries, including suppliers and clients (MOORI;MARCONDES; AVILA, 2002). The SCM is an integrated network where companies dispatch goods and services to their customers (POIRIER; REITER, 1997). The SCM is a strategic area that can affect 
DOI: 10.14807/ijmp.v10i4.1001

the competitiveness (ANDERSEN; LARSEN, 2009), the main goal of SCM is to maximize the global value created, which is the difference between final price to consumer and the efforts along the SCM to fulfill the order (CHOPRA; MEINDL, 2003). Procurement represents the greatest part of financial expenses for companies, it reinforces the view of SCM as a vital field to be explored (SLACK et al., 1996).

Transportation activities have great impact on SCM, being a key activity on logistics of distribution and is significant on costs impact, in some cases it represents $60 \%$ of logistical costs, which means that wrong decisions can cause profit reduction and loss of competitiveness (BALLOU, 2006).

According to data from Confederação Nacional do Transporte (CNT, 2016), transportation costs represent $6.8 \%$ of GNP ( $\$ 401$ billion), and logistical costs can be $25 \%$ of final goods.

Choose the correct mode of transportation is very important to dispatch goods and services, it demands planning the dispatch that best satisfy customer needs, according to CNT (2018), the main mode utilized in Brazil is by road $60 \%$, followed by rail $20 \%, 13 \%$ waterway. Comparing to other countries these proportions varies, for example in USA it is $32 \%-43 \%-25 \%$, in Russia it is $8 \%-81 \%-11 \%$ (CARNEIRO, 2016, p. 21). According to Wanke (2010), the national transportation production (moved amount vs travelled distance) has over $60 \%$ of road transport. The preference to road transportation is justified by logistical fundaments such as the spread of the road need (ARAUJO, 2014).

This field does not suffer interference of government control, it allows that prices can be negotiated by who offers and buys transportation services (SOARES; CAIXETA-FILHO, 1997). Prices formation is a very complex process, due to it depends on the activity costs, local and conjuncture factors (MARTINS, 2008). Freight prices also can be different according to the rout, areas with higher demand on good transportation, usually have more expensive freight prices (HIJJAR, 2008).

Third part transportation suppliers reflect the enterprise image to customers, showing how much care is given to distribution services, it is part of the front line with customers such as treatment offered by telephone, e-mails and other communications, so it makes necessary a careful attention to this issue because is the view clients have from the company, transportation is the column of distribution compound, having 
straight impact on client's satisfaction (MARTINS et al., 2014). According to Ballou (2006), delivery services can cause a negative impact on global evaluation from the client, as an example it can cause loss of fidelity or non-repetition of purchase, depending on delivery performance affected by product damage, delay or inconsistent services.

The choice of transportation supplier is a strategic issue, it is necessary to evaluate reliability, safety, on time delivery history, costs as well as attention to client's special needs (MARTINS et al., 2011), it is also important to guarantee service consistency, availability and time (MARTINS; LOBO; PEREIRA, 2005).

Costumers aims more than goods, they search for good treatment, quality, flexibility payment and delivery term, reliability is hard to build and take time, but a small sequence of problems and lack of commitment can destroy a long-term relationship (SLACK et al., 1993). On time delivery starts before shipment, to have an efficient logistical planning, it is necessary to know the real situation about delivery terms, equipment's availability and other services required (KAFER; PARIS, 2010), according to Barros, Fensterseifer e Formoso (2003), fulfilling the promised terms creates reliability to customers.

Another important issue to create customer reliability os post-sales services, consumers can react in a negative way if after sales support is inefficient, it possibly will make customer think better before making a new purchase (ALMEIDA et al., 2017). When a company is consumer satisfaction focused it creates competitive advantages (GONÇALVES, 1995), companies need to satisfy its consumers, after all they provide sustainability when satisfied they maintain long-term relationships that results in competitiveness (GUARNIERI et al., 2006).

Satisfying consumer needs is one of the organizations main objectives, for that reason many studies were developed on this subject (MARCHETTI; PRADO, 2001). Consumer satisfaction is defined as the answer given by the customer related to the provided services during the process of customer attendance, that is the result of comparison between the expectations and the provided services (SANTOS; NEIVA; MELO, 2013).

To measure consumer satisfaction, it is possible to utilize performance indicators, that are tools to evaluate a situation and environmental trends 
(TORCCHETO; PEREIRA, 2004). Performance indicators are parameters utilized to have information and monitoring the company's performance based on stablished standards for this purpose (CHAVES; ASSUNÇAO, 2008).

To measure customer's satisfaction Fred Reichheld proposed in 2003 a performance indicator named Net Promoter Score (NPS), which focus on positive and negative recommendations have influence on corporation growth (KEININGHAM, 2008). The calculation of NPS is demonstrate on equation 1.

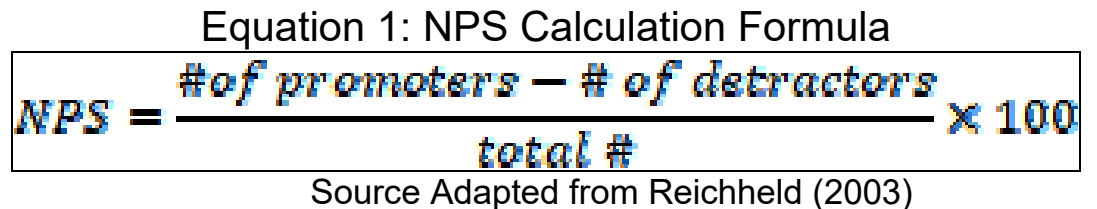

Where:

Promoters (score 9 and 10): are customers that will really exalt the company on a propitious moment, telling their good experiences.

Neutral (scores 7 and 8): these are consumers that will neither exalt nor depreciate the company.

Detractors (scores 0 to 6): customers that will depreciate the company highlighting the bad experiences they had with the company.

\section{RESEARCH METHODOLOGY}

Exploratory research is carried out to provide to the researcher more familiarity with the problem, this kind of research can be conducted as a Case Study (GIL, 2002). Case Study is a research method used in many situations, it can contribute to better understanding phenomena of many natures, including corporations (YIN, 2010).

To better develop and support the Case Study, it is recommended that the researcher previously prepares a research protocol, it needs to contain a setting of tools that allows a deep observation of the phenomenon (YIN, 2010). The present research started with a bibliographic research to provide a better view of the problem to be studied and set basis to develop the other phases, during data collection and analysis the utilized tools were interviews, non-participatory observation, participatory observation with improvement suggestions implementation and research on corporation's documents. 
DOI: 10.14807/ijmp.v10i4.1001

\section{CASE STUDY}

The research took place in a corrugated paperboard company situated in the east area of the Citi of São Paulo. The data collection for the occurred from April to September of 2017, based on performance indicators from logistics and marketing departments.

The data about logistics processes were taken from a satisfaction research performed on June 2017, based on NPS method, that made possible to identify the most critical factors listed below.

- Freight costs based on weight of transported cargo, also allowing to identify the freight margins.

- Product devolution caused by logistic problems that has returned merchandise weight divided by total production weight, providing the percentage of devolution.

- On time delivery that show how many customers are satisfied with time delivery fulfillment, indicates the percentage of contacted customers satisfied with delivery services.

- Third part transport services, measures customers satisfaction with provided services considering ethics, treatment and merchandise preservation.

- General satisfaction measures how satisfied customers are with the company, based in quantity of contacted customers.

In the first part of the Case Study there the process was observed without interference of the researches, non-participative observation, according to Gil (2002), this process can change the behavior on the observed people due to the presence of observers. Meantime the company documentation was checked to verify the critical factors found on the satisfaction research. The financial results were provided in percentage format, without details due to the confidentiality of discussed information.

During the study development improvement suggestions came up based on previous observations and were implemented, at this point the started the participative observation process. To validate the research on company's documents the logistics 
Manager and Analysts were interviewed, it made possible to enhance the perception on processes and implemented during the research.

\subsection{Data analysis}

The data analysis occurred two periods, the first was from April to June, when there was the collection from logistical processes data, nom-participative observation and interviews, that made possible to non-controlled and non-evaluated processes, the satisfaction survey on performed on July to check the satisfaction on previous trimester was also utilized.

The second part occurred from July to September, when there was the implementation of new control system of logistical processes based on the first phase of the research, that allowed to suggest improvements. The evaluation on the improvements impact was carried out on October based on a satisfaction survey performed with customers.

\subsection{Freight costs}

The Company distributes all over the country, however, its biggest Market is the southeast region of Brazil, mainly São Paulo State, the chart 1 presents freight costs related to the production on the evaluated period.

Chart 1: freight costs

\begin{tabular}{|c|c|c|}
\hline \multicolumn{3}{|c|}{ Freight Costs } \\
\hline Period & Production Kg & Costs \% \\
\hline April & 750 & 0.49 \\
\hline May & 550 & 0.61 \\
\hline June & 700 & 0.52 \\
\hline Total & 2000 & 1.62 \\
\hline Average & 667 & 0.54 \\
\hline \multicolumn{2}{|c|}{ Source: created by the author }
\end{tabular}

The company produced two metric ton from April to June, and had a transportation cost of $0.54 \%$, considered high by the corporation, costs above $0,5 \%$ are considered high and have great impact on competitiveness. Before the research the company did not related freight costs with production, so it was not possible to compare to past periods.

After the transportation analysis it was proceeded price quotations with transportation suppliers for two months, after that $70 \%$ of regular suppliers accepted to negotiate and continued to supply the company, the other $30 \%$ were changed by new supplier. The new price condition creates a financial return as shown on chart 2 . 
Chart 2: freight costs after changes

\begin{tabular}{|c|c|c|}
\hline \multicolumn{3}{|c|}{ Freight Costs } \\
\hline Period & Production Kg & Costs \% \\
\hline July & 650 & 0.45 \\
\hline August & 690 & 0.41 \\
\hline September & 670 & 0.43 \\
\hline Total & 2010 & 1.29 \\
\hline Average & 670 & 0.43 \\
\hline
\end{tabular}

Source: created by the authors

As observed the production was practically the same, but there was a reduction in freight costs from $0.54 \%$ to $0.43 \%$, representing $20 \%$ of reduction;

\subsection{Logistical problems devolution}

Checking consumers claims, it was possible to verify problems with products identification on packaging as well as identification tags, the level of devolutions can be observed on chart 3 .

Chart 3: logistical problem claims

\begin{tabular}{|c|c|c|c|c|}
\hline \multicolumn{5}{|c|}{ Logistical problems claims } \\
\hline Period & Claims & Logistics & Devolution & $\%$ \\
\hline April & 23 & 3 & 2 & 13.04 \\
\hline May & 27 & 2 & 1 & 7.41 \\
\hline June & 22 & 2 & 1 & 9.09 \\
\hline Total & 72 & 7 & 4 & 9.72 \\
\hline Average & 23 & 2 & 1 & 8.70 \\
\hline
\end{tabular}

Source: created by the authors

The chart presents that from April to June logistical problems were responsible for $8.7 \%$ of total devolution, as far as the company does not consider it as a relevant problem, actions are needed to reduce this indicator. Chart 4 presents the percentage of logistical problems devolution compared to total production.

Chart 4: \% of returned quantities before process modifications

\begin{tabular}{|c|c|c|c|}
\hline \multicolumn{4}{|c|}{ Logistical problems devolutions } \\
\hline Period & Production Kg & Devolution Kg & $\%$ \\
\hline April & 750 & 5 & 0.67 \\
\hline May & 550 & 2 & 0.36 \\
\hline June & 700 & 3 & 0.43 \\
\hline Total & 200 & 10 & 0.5 \\
\hline Average & 667 & 3 & 0.45 \\
\hline \multicolumn{4}{|c}{ Source: created by the authors } \\
\hline
\end{tabular}

On average there was $3 \mathrm{Kg}$ of logistical problems devolutions representing $0.45 \%$ of total production

From the observations of processes changes were suggested in the processes of material check and production notes, a on the job training program was performed, 
INDEPENDENT JOURNAL OF MANAGEMENT \& PRODUCTION (IJM\&P)

http://www.ijmp.jor.br

v. 10, n. 4, Special Edition IFLOG 2018

ISSN: 2236-269X

DOI: 10.14807/ijmp.v10i4.1001

after the changes were implemented it was possible do evaluate the effects as demonstrate on charts 5 and 6 .

Chart 5: historical of logistical problems claims after changes

\begin{tabular}{|c|c|c|c|c|}
\hline \multicolumn{5}{|c|}{ Logistical problems claims } \\
\hline Period & Claims & Logistics & Devolutions & $\%$ \\
\hline July & 21 & 2 & 1 & 9.52 \\
\hline August & 18 & 1 & 1 & 5.56 \\
\hline September & 15 & 1 & 0 & 6.67 \\
\hline Total & 54 & 4 & 2 & 7.41 \\
\hline Average & 18 & 1 & 1 & 5.56 \\
\hline
\end{tabular}

Source: created by the authors

Comparing results from charts 3 and 5 it is possible to observe that the processes changes caused a reduction of unconformities from $8.7 \%$ to $5.56 \%$ a total reduction of $36 \%$.

The chart 6 presents the results of the indicator of logistical problems devolution compared to total production after procedures changes.

Chart 6: \% of returned quantities before process modifications

\begin{tabular}{|c|c|c|c|}
\hline \multicolumn{4}{|c|}{ Logistical problems devolutions } \\
\hline Period & Production Kg & Devolution Kg & $\%$ \\
\hline July & 650 & 3 & 0.46 \\
\hline August & 590 & 2 & 0.29 \\
\hline September & 670 & 1 & 0.15 \\
\hline Total & 2000 & 6 & 0.30 \\
\hline Average & 667 & 2 & 0.30 \\
\hline \multicolumn{4}{|c}{ Source: created by the authors }
\end{tabular}

Comparing charts 4 and 6 ir is possible to observe a reduction from $0.45 \%$ to $0.30 \%$ on devolutions, it represents an improvement of $33 \%$ on the indicator.

\subsection{Deadline accomplishments}

The satisfaction survey made on June revealed that $78 \%$ of customers were satisfied with the company's deadline accomplishments, other 22 were dissatisfied. After checking the invoices that present deadline problems it was observed that the problem source was in the production planning, some adjustments on production scheduling were made, but due to the lack of time, it was not possible to observe the impacts on deadline accomplishments.

\subsection{Third part transportation services}

The satisfaction survey performed on June presented indicated that $81 \%$ of consumers are satisfied with transportation services and $19 \%$ dissatisfied, extracting information from the reports it was possible to identify the main causes of 
DOI: 10.14807/ijmp.v10i4.1001

dissatisfaction, merchandise preservation, treatment, worker behavior and vehicle preservation. The collected data is presented on chart 7 .

Chart 7: claims on third part transportation companies

\begin{tabular}{|c|c|c|}
\hline \multicolumn{3}{|c|}{ Third part transportation claims } \\
\hline Requirement & \% claim & \%accumulated \\
\hline Merchandise preservation & 43 & 43 \\
\hline Treatment & 29 & 72 \\
\hline Worker behavior and & 18 & 90 \\
\hline Vehicle preservation & 10 & 100 \\
\hline Total & \multicolumn{1}{c}{} \\
\hline \multicolumn{2}{|c|}{ Source: Criated by the authors } \\
\hline
\end{tabular}

Based on the information above it was requested, to the transportation supplier to produce and implemented corrective plans, due to the lack of time to evaluate the results, the only information obtained is that on September satisfaction survey the dissatisfied level was $17 \%$, but this data cannot be considered an improvement, since it is necessary a long-time observation to evaluate this indicator.

\section{RESULTS ANALYSIS}

After data collection interviews with the Logistics Manager and the two Logistics Analysts were performed to validate the processes control changes implemented. Their perception was that the most important issues that impact costumer's satisfaction are the deadline accomplishments and third part transportation services, due to the research duration, it was not possible to achieve conclusive results, since there was not enough time to observe the impact of production scheduling changes and action plans implementation by third part transportation suppliers.

The Direction board decide a goal of minimum $80 \%$ on satisfaction indicator, even with the change to NPS that is more severe than previous methodology, it was decided to keep $80 \%$ as minimum score, NPS was calculated using the formula on equation 1.

On July it was performed a customer survey with 102 clients, covering the trimester from April to June, the data was collected to fulfill the old method of consumer satisfaction analysis, but it was possible to convert to NPS standards, the results are available on chart 8 . 
DOI: 10.14807/ijmp.v10i4.1001

Chart 8: NPS indicators from April to June

\begin{tabular}{|c|c|c|}
\hline \multicolumn{3}{|c|}{ April to June Trimester } \\
\hline NPS & Clients amount & $\%$ \\
\hline Promoters & 81 & 64 \\
\hline Neutral & 13 & 24 \\
\hline Detractors & 8 & 12 \\
\hline Total & 102 & 100 \\
\hline NPS & \multicolumn{2}{|c|}{$\mathbf{7 2 \%}$} \\
\hline
\end{tabular}

Source: created by the authors

On October the research was performed with 105 clients covering the trimester from July to September, the results are available on chart 9.

Chart 9: NPS indicators from July to Septem
\begin{tabular}{|c|c|c|}
\hline \multicolumn{3}{|c|}{ April to June Trimester } \\
\hline NPS & Clients amount & $\%$ \\
\hline Promoters & 92 & 64 \\
\hline Neutral & 8 & 24 \\
\hline Detractors & 5 & 12 \\
\hline Total & 105 & 100 \\
\hline NPS & \multicolumn{2}{|c|}{$\mathbf{8 3}$} \\
\hline
\end{tabular}

Source: created by the authors

Comparing the results from the semesters it is possible to observe the improvement on customer satisfaction based on NPS, there was a growth of $11 \%$ on satisfaction indicators, and the company could achieve a result in line with the board determination of $80 \%$, achieving $83 \%$. Checking the financial data it was also possible to observe that the financial results kept stable with a small growth of $0.38 \%$.

\section{FINAL CONSIDERATIONS}

During the improvement process implementation, it was clear the resistance to changes form the involved employs, comments such as we have a large experience in company, even the among the leaders it was possible to note a discomfort with changing subjects.

It was possible to observe that the company had performance controls, but a small attention was given to them, even the leadership was not engaged on making it work. During the training program to implement the proposed changes in logistics control procedures, as far as there was resistance, it was possible to convince worker to accept and understand the benefits of the changes.

The study allowed to observe a cost saving transportation problems devolutions, as well as on customer satisfaction based on NPS results with an increase or $11 \%$ on customer satisfaction indicator. 
DOI: 10.14807/ijmp.v10i4.1001

It was possible to observe that some people in the company started to compare the results of new performance indicators with the old ones, causing a sensation of decrease on results, that was necessary to recalculate the previous results adapted to NPS, so they could understand the advantages of the changes performed, and that it is not recommended compare results based on different methods.

The Case Study was performed only on logistics department, based on the positive results it is recommended to extend the process improvement to the whole company, and suggest a continuous improvement program implementation to create a culture of improvement to guarantee the business sustainability.

\section{REFERENCES}

ANDERSEN, M.; SKJOETT-LARSEN, T. (2009) Corporate social responsibility in global supply chains. Supply Chain Management: An International Journal, v. 14, n. 2, p. 75-86.

ARAUJO, M. P. S.; BANDEIRA, R. A. M.; CAMPOS, V. B. G. (2014) Custos e fretes praticados no transporte rodoviário de cargas: uma análise comparativa entre autônomos e empresas. J. Transp. Lit., Manaus, v. 8, n. 4, p. 187-226, Oct.

ABRE. ASSOCIAÇÃO BRASILEIRA DE EMBALAGENS (2017) Available em: $<$ http://www.abre.org.br/noticias/setor-de-embalagem-preve-crescimento-de-296em-2018-maior-do-que-registrado-em-2017/>. Access: 30 ago. 2018.

ALMEIDA, C. X. et al . (2017) Resolveram meu problema, porém não compro mais! Por que os consumidores não desejam voltar a fazer negócios em lojas on-line? Innovar, Bogotá, v. 27, n. 65, p. 57-68.

BALLOU, R. H. (2006) Gerenciamento da Cadeia de Suprimentos/Logística Empresarial. 5. ed. Porto Alegre: Bookman.

BALLOU, R. H. (2001) Gerenciamento da cadeia de suprimentos: Planejamento, organização e logística empresarial. Porto Alegre: Bookman.

BARROS NETO, J. P.; FENSTERSEIFER, J. E.; FORMOSO, C. T. (2003) Os critérios competitivos da produção: um estudo exploratório na construção de edificações. Revista de Administração Contemporânea. Curitiba, v. 7, n. 1, p. 6785, mar.

BRACELPA. ASSOCIAÇÃO BRASILEIRA DE CELULOSE E PAPEL (2016), SÃO PAULO.

CARNEIRO, C. C. (2016) Multimodalidade: Conceitos, Análises e Limitações para o Caso Brasileiro, Brasília, 2016.

CASAGRANDA, Y. G.; SAUER, L.; PEREIRA, M. W. G. (2016) A percepção dos administradores sobre sustentabilidade empresarial. Interações, Campo Grande, v. 17, n. 3, p. 487-502, set.

CHAVES, G. L. D.; ASSUNÇÃO, M. R. P.(2008) Medidas de desempenho na logística reversa: o caso de uma empresa do setor de bebidas. In: SIMPÓSIO DE 
INDEPENDENT JOURNAL OF MANAGEMENT \& PRODUCTION (IJM\&P)

http://www.ijmp.jor.br

v. 10, n. 4, Special Edition IFLOG 2018

ISSN: 2236-269X

DOI: 10.14807/ijmp.v10i4.1001

ADMINISTRAÇÃO DA PRODUÇÃO, LOGÍSTICA E OPERAÇÕES

INTERNACIONAIS - SIMPOI, 11, São Paulo. Anais... 2008.

CHOPRA, S.; MEINDL, P. (2003) Gerenciamento da cadeia de

suprimentos: Estratégia, planejamento e operação. São Paulo: Prentice Hall.

CHRISTOPHER, M. (1997) Logística e gerenciamento da cadeia de

suprimentos. São Paulo: Pioneira.

CNT. CONFEDERAÇÃO NACIONAL DOS TRANSPORTES (2016). Notícias (2016), Custo logístico consome 12,7\% do PIB do Brasil. Available em: <http://www.cnt.org.br/Imprensa/noticia/custo-logistico-consome-12-do-pib-dobrasil>. Access 10 set. 2018.

CNT. CONFEDERAÇÃO NACIONAL DOS TRANSPORTES (2018) Boletim

Estatístico. Available em: <http://www.cnt.org.br/Boletim/boletim-estatistico-cnt >. Access 10 set. 2018.

EVANGELISTA, R. (2010) Sustentabilidade Um possível caminho para o sucesso empresarial? Revista Portuguesa e Brasileira de Gestão, Lisboa, v. 9, n. 1-2, p. 85-96, jun.

FATAS, A.; SUMMERS, L. H. (2016) The permanent effects of fiscal consolidations. NBER Working Paper, n. 22374, jun.

FONSECA, W. (2017) Gestão por Processos, Diferenças entre a visão departamental e visão por processos. Available em:

$<$ http://www.administradores.com.br/artigos/carreira/gestao-por-processosdiferenca-entre-a-visao-departamental-e-visao-por-processos/38869/>. Access 25 Set. 2017.

GIL, A. C. (2010) Como Elaborar Projetos de Pesquisa, São Paulo - SP: Métodos e Técnicas de Pesquisa Social. 6 ed. São Paulo: Atlas.

GONÇALVES, M. A. (1995) A satisfação dos clientes de uma organização é diretamente proporcional à valorização efetiva de seus recuros humanos: as organizações perdem, primeiro, o foco em seu pessoal antes de perderem o foco em seus clientes. Revista de Administração de Empresas, São Paulo, v. 35, n. 1, Feb.

GUARNIERI, P. et al. (2006) Wms - Warehouse management system: Adaptação proposta para o gerenciamento da logística reversa, São Paulo, v. 16, n. 1, p. 126139, Apr.

GURGEL, F. A. (2000) Logística Empresarial, São Paulo, Editora Atlas.

HIJJAR, M. F. (2008) Preços de frete rodoviário no Brasil. Rio de Janeiro: ILLOSInstituto de Logística e Supply Chain.

KAFER, E.; PARIS, W. S. (2010) Avaliação da Eficiência da Cadeia de Fornecedores da Prefeitura de Céu Azul; Curitiba.

KEININGHAM, T. L. (2008) Linking Customer Loyalty to Growth, MIT Sloan Management Review, v. 49, n. 4, p. 52.

L'ASLOG. (2010) The association française des logisticiens d'enterprises, Paris,. 
LANDIM, A. P. M. et al. (2016) Sustentabilidade quanto às embalagens de alimentos no Brasil. Polímeros, São Carlos, v. 26, n. spe, p. 82-92.

MARCHETTI, R.; Prado, P. H. M. (2001) Um tour pelas medidas de satisfação do consumidor. Revista de Administração de Empresas, v. 41, n. 4, p. 56-67.

MARTINS, R. S. et al. (2011) Gestão do Transporte Orientada para os Clientes: Nível de Serviço Desejado e Percebido. RAC. Revista de Administração Contemporânea, v. 15, p. 1100-1119.

MARTINS, R. S.; LOBO, D. S.; PEREIRA, S. M. (2005) Atributos relevantes no transporte de granéis agrícolas: Preferência declarada pelos embarcadores. Revista de Economia e Agronegócio, Viçosa - UFV, v. 32, n. 2, p. 173-192.

MARTINS, R. S. et al. (2014) Fatores relevantes na contratação de serviços em terminais intermodais para granéis agrícolas. Revista de Economia e Sociologia Rural, Brasília, v. 52, n. 2, p. 347-364, jun.

MARTINS, S. (2008) Estudo da formação do frete rodoviário e potencial de conflitos em negociações. Cadeias do agronegócio Brasileiro, vol. 10, n. 1, p. 73-87.

MOORI, R. G.; MARCONDES, R. C.; AVILA, R. T. (2002) A análise de agrupamentos como instrumento de apoio à melhoria da qualidade dos serviços aos clientes. Revista de Administração Contemporânea, Curitiba, v. 6, n. 1, p. 63-84, abr.

PAULA, L. F.; PIRES, M. (2017) Crise e perspectivas para a economia brasileira. Estud. av., São Paulo, v. 31, n. 89, p. 125-144, abr.

POIRIER, C. C.; REITER, S. E. (1997) Otimizando sua rede de negócios. São Paulo: Futura.

RISI (2010) PULP AND PAPER INDUSTRY INTELLIGENCE. Satistical Boltim 2010. Bedford.

REICHHELD, F. (2003) The One Number you Need to Grow. Harvard Business Review. v. 83, n. 6.

SANTOS, J. N.; NEIVA, E. R.; MELO, E. A. (2013) Relação entre clima organizacional, percepção de mudança organizacional e satisfação do cliente. Psic.: Teor. e Pesq., Brasília, v. 29, n. 1, p. 31-39, mar.

SLACK, N. et al. (1996) Administração da Produção. São Paulo: Atlas.

SLACK, N. (1993) Vantagem competitiva em manufatura: atingindo competitividade nas operações industriais. São Paulo: Atlas.

SOARES, M. G.; CAIXETA FILHO, J. V.(1997) Caracterização do mercado de fretes rodoviários para produtos agrícolas. Gest. Prod. São Carlos, v. 4, n. 2, p. 186204, Aug.

SOUZA, C. A.; ZWICKER, R. (2003) Big-bang, small-bangs ou fases: estudo dos aspectos relacionados ao modo de início de operação de sistemas ERP. Revista de Administração Contemporânea, Curitiba, v. 7, n. 4, p. 9-31, Dec.

TOCCHETTO, M. R. P; PEREIRA, L. C. (2004) Seleção de indicadores ambientais para indústria com atividade galvânica. In: ENCONTRO DA ASSOCIAÇÃO NACIONAL DE PÓS-GRADUAÇÃO E PESQUISA EM ADMINISTRAÇẪO, 28, Curitiba. Anais... Paraná: Anpad, 2004. CD-ROM. 
ISSN: 2236-269X

DOI: 10.14807/ijmp.v10i4.1001

WANKE, P. (2010) Logística e transporte de cargas no Brasil: produtividade e eficiência no Século XXI. São Paulo: Atlas.

YIN, R. K. (2010) Estudo de Caso: planejamento e métodos. 4ª edição, Porto Alegre. Bookman. 